Dr Dragan Lazarević, pukovnik, dipl. inž. Mr Zoran Popović, pukovnik, dipl. inž. Vojnotehnicka akademija VJ. Beograd

\section{MODERNIZACIJA BORBENIH VOZILA U PROCESU TEHNIČKO-TEHNOLOŠKOG OSAVREMENJAVANJA VOJSKE}

UDC: 623.438 .001 .76

Rezime:

Tehnička sredstva koja se nalaze u naorużanju armija vrlo brzo zastarevaju i postaju inferiorna $u$ odnosu na protivnika koji prati trendove razvoja borbenih sredstava $i$ sistema, $i$ u skladu sa tim naorużava svoju armiju. Jedan od vrlo racionalnih $i$ efikasnih nacina za dostizanje tehnickog nivoa moguceg protivnika jeste modernizacija postojecih sredstava naorużanja $i$ vojne opreme. Dobro pripremljena $i$ efikasno sprovedena modernizacija, na vrlo racionalan i ekonomski opravdan nacin, povecava nivo borbene gotovosti $i$ efikasnosti borbenih sredstava $i$ sistema, i zbog toga se sve vise primenjuje u svetu.

Ključne reči: modernizacija, efikasnost, borbena sredstva, tenk.

\title{
MODERNIZATION OF MILITARY VEHICLE IN THE PROCESS OF TECHNICAL AND PRODUCTIONAL RENEWALL OF THE ARMY
}

\begin{abstract}
Summary:
Military technical resources grow old very quickly and become inferior to those of the enemy who follows trends in development of arms and combat systems and accordingly equip its army. One of very rational and efficient ways of reaching the technical level of a possible enemy is modernization of existing arms and military equipment. Well prepared and efficiently carried out modernization improves the level of combat readiness and effectiveness of military equipment in a very rational and economically justified way, and therefore it is very often applied in the world.
\end{abstract}

Key words: modernization, efficiency, military equipment, tank.

\section{Uvod}

Jedan od najbitnijih faktora za ocenu moći i mogućnosti armija jeste efikasnost (ubojitost) borbenih sredstava i sistema koji se nalaze u naoružanju.

Efikasnost zavisi od mnogo parametara, ali u suštini, pri razmatranju tog pitanja postavlja se osnovna dilema koliko su borbena sredstva i sistemi kojima raspolaže određena armija spremna i sposobna da se suprotstave sredstvima mogućeg protivnika. Drugačije rečeno, pored stanja tehnicke ispravnosti, kao bitnog parametra za upotrebu, analiziraju se taktičko-tehničke karakteristike (TTK) borbenih sredstava posmatrane armije, u odnosu na TTK sličnih ili istih borbenih sredstava i sistema, koja se nalaze u naoružanju ostalih armija sveta, odnosno kod potencijalnog protivnika.

Opremanje armije efikasnim borbenim sredstvima moguće je obaviti na sledeće načine: 
zemlje,

- proizvodnjom u fabrikama svoje

- nabavkom na svetskom tržištu,

- modernizacijom postojecih borbenih sredstava i sistema, bilo da su proizvedena u fabrikama domaće industrije ili nabavljena uvozom.

\section{Ekonomski činioci sopstvene proizvodnje sredstava NVO}

Proizvodnja borbenih sredstava i sistema (sredstava naoružanja i vojne opreme - NVO) vrlo je skupa i cesto neracionalna, posebno ako se izvodi samo za potrebe svoje armije. Malo je zemalja u svetu koje mogu da organizuju racionalnu i ekonomski opravdanu proizvodnju sredstava NVO samo za svoje potrebe. To je posebno izraženo kada su u pitanju složeni borbeni sistemi i male zemlje sa odbrambenom vojnom doktrinom i nedovoljnom ekonomskom moći.

Ocenu racionalnosti proizvodnje pojedinih vrsta sredstava NVO, posmatrano u ekonomskom smislu, koja se mora sprovesti pre početka bilo kakvog ozbiljnijeg razmišljanja o proizvodnji ili, bolje rečeno, pristupa pripremi proizvodnje (pri projektovanju) moguće je posmatrati sa više aspekata.

$\mathrm{Na}$ osnovu analize eksperata koji se bave organizacijom proizvodnje tenkova kao borbenih sistema, nameće se zaključak da je organizacija racionalne proizvodnje ovog sredstva moguća ukoliko je u određenom periodu obezbeđeno tržište za godišnju produkciju od oko 150 komada. Da bi se opravdala uložena investicija, proizvodnja treba da traje najmanje 10 godina. Malo je zemalja u svetu kojima treba toliki broj sredstava, što odmah povlači pitanje mogućnosti njegove pro- daje na svetskom tržištu. Međutim, konstatacija o veličini serije odgovara samo za tenk kao celinu. Proizvodnja odgovarajućih delova, sklopova, pa i uređaja, koji ulaze u sastav tenka, ima sasvim drugačije kriterijume za racionalnost organizacije godišnje proizvodnje. Primera radi, organizacija racionalne proizvodnje motora za pogon tog tenka moguća je samo ukoliko godišnja serija nije manja od 700 primeraka, dok se to isto za neke električne komponente kreće i po nekoliko hiljada komada. Prema tome, kada se razmatraju ekonomski aspekti racionalnosti organizacije proizvodnje nekog sredstva NVO i njegovih sastavnih komponenata, dolazi se do vrlo različitih podataka za sistem kao celinu i njegove sastavne delove.

Odmah se može postaviti pitanje šta raditi sa komponentama koje se ugrađuju u sistem, a njihova ekonomski opravdana proizvodnja nije moguća u seriji u kojoj se proizvodi osnovno sredstvo NVO? Jedan od odgovora na to pitanje može biti da se paralelno sa proizvodnjom novog sredstva NVO, njegovi sastavni delovi koriste i za modernizaciju drugih sredstava i sistema u naoružanju armije. Na taj način postiže se više pozitivnih efekata, a jedan od osnovnih je unifikacija delova, sklopova i uređaja koji su ugrađeni u sredstva NVO, pa i šire, čime se olakšava održavanje.

Međutim, bez obzira na ovaj ekonomski kriterijum razmatranja racionalnosti proizvodnje nekog sredstva, ekonomska opravdanost se može posmatrati i sa stanovišta mogućnosti, odnosno nemogućnosti nabavke tog sredstva uvozom (naročito u kriznim situacijama), a ono može biti bitno za odbranu zemlje. I tada se razmatraju ekonomski aspekti, ali sa drugih polaznih pozicija. 
Faktori koji utiču na vek upotrebe tehničkih sredstava

Prati li se vreme upotrebe bilo kog složenog sredstva NVO, proizvedenog u industrijski razvijenim zemljama, videće se da se ono stalno usavršava, a njegova proizvodnja traje sve dok traje i njegovo usavršavanje. Onog trenutka kada prestaje usavrక̌avanje vrlo brzo prestaje i proizvodnja. U proizvodnji novih sredstava u većim serijama $i$ više godina, svaki konstruktor određenog sklopa ili uređaja mora svake godine da uvede neku racionalizaciju u smislu pojeftinjenja proizvodnje i povećanja efikasnosti konkretnog sredstva, sklopa ili uređaja.

Sredstva NVO, u principu, vrlo brzo zastarevaju a da prethodno nisu eksploatisana u meri u kojoj im to omogućavaju njihovi projektovani radni resursi. To posebno postaje izraženo pri brzom razvoju nauke i tehnike koja nalazi primenu u praksi. Novoproizvedena sredstva su sve ubojitija i imaju bolje performanse od ranije proizvedenih sredstava. Samim tim, ranije proizvedena postaju inferiorna na ratištu. Vrlo složena i skupa, a za borbenu gotovost bitna sredstva postaju relativno brzo (za manje od petnaest godina) zastarela. Ukoliko se ne preduzimaju mere za podizanje borbenih mogucnosti, putem modifikacija i modernizacija, biće vrlo teško da dostignu i pomenuti životni vek. Razvoj tehnike i tehnologije na kraju dvadesetog veka, primena informatičke tehnologije $\mathrm{i}$ intenzivan razvoj digitalne $i$ softverske kontrole svih vrsta upravljanja funkcijama tehničkih sredstava zahtevaju stalni rad na modernizacijama sredstava NVO. Prevashodnu ulogu u tome moraju da odigraju savremeni mikrodigitalni, elektromehanički, elektronski, telekomunikacijski i drugi podsistemi i sklopovi, koji imaju veoma ograničen generacijski vek. Normalno se tada postavlja pitanje ekonomičnosti njihovog uvođenja u naoružanje. Ekspanzija razvoja novih materijala i tehnologija stalno smanjuje granicu efikasne operativne upotrebljivosti sredstava NVO. Pocetkom dvadesetog veka veće promene u razvoju tehnike i naoružanja događale su se svakih dvadeset do trideset godina, a u ovom vremenu svake 2 do 3 godine. Prosečno vreme korišćenja određenog modela ratne tehnike sada iznosi tri do pet godina, a borbeni sistemi i pojedinačna sredstva zastarevaju svakih 7 do 10 godina.

Pri razmatranju problema modernizacije određenog sredstva NVO mora se razmotriti i mogućnost da li će modernizovano sredstvo biti efikasno na ratištu (da li će moći efikasno da se suprotstavi sredstvima mogućeg protivnika) u odgovarajućem periodu upotrebe, a ako to nije moguće obezbediti, odmah treba preispitati (doraditi, dopuniti ili odustati) planirani postupak modernizacije.

$\mathrm{Za}$ efikasnu primenu sredstava NVO u životnom veku, vrlo je bitno obezbediti adekvatan stok rezervnih delova radi održavanja $u$ ispravnom stanju. Zbog prethodno navedenih razloga to nije uvek moguće obezbediti, jer se zbog uvođenja novih tehnologija stare napuštaju, a mnogi rezervni delovi, najčesće, sa ogranicenim vremenom trajanja i upotrebe ne mogu da se proizvedu. Postavlja se neizbežno pitanje - šta u tim uslovima treba raditi sa vrlo skupim borbenim sistemom? Razvijene zemlje, sa primenjenim najsavremenijim tehnologijama u proizvodnji, takvo sredstvo ne rashoduju - otuđuju, već korišcenjem tehnologija razvijenih i primenjenih na novim sredstvima NVO, ugradnjom novih sklopova, uređaja i si- 
stema, modernizuju zastarelo sredstvo, cime mu obezbeđuju novi životni ciklus.

\section{Pravci modernizacije postojećih tehničkih sredstava}

Da bi se predupredilo rashodovanje složenih a istovremeno $\mathrm{i}$ vrlo skupih sredstava NVO, u svetu se sve više radi na razvijanju sistema modernizacije zastarelih i neefikasnih sredstava NVO i borbenih sistema. Zemlje koje imaju osvojenu proizvodnju novih, savremenih sredstava i sistema NVO, za njihovu proizvodnju imaju razvijene komponente, pa i kompletne sisteme, koji se mogu vrlo efikasno i ekonomično upotrebiti za modernizaciju sredstava i borbenih sistema. U tom slucaju posao oko modernizacije je bitno olakšan.

Problem modernizacije sredstava i borbenih sistema NVO zaslužuje, posebno u kriznim vremenima, izuzetno veliku pažnju. Poželjno je da se paralelno sa razvojem novih sredstava razmišlja i o modernizaciji sličnih sistema komponentama koje se razvijaju za novo sredstvo. Modernizacija sredstava i borbenih sistema NVO sigurno predstavlja vrlo znacajan izvor opremanja vojske efikasnim sredstvima NVO, na racionalan i ekonomičan način.

U principu, razlikuju se dva načina, odnosno dve vrste zahvata na usavršavanju sredstava i borbenih sistema NVO radi podizanja njihove efikasnosti, a to su: modifikacija i adaptacija.

Pod uslovom da se pravovremeno planira, organizuje i izvodi brzo i efikasno, modernizacija predstavlja najjeftiniji i najefikasniji način da se podigne tehnički nivo sopstvenih sredstava, i dostigne nivo mogućeg protivnika, odnosno, da se u nekim slučajevima i vrlo racionalno pretekne. Sve to nije moguće uraditi ukoliko u serijskoj proizvodnji nisu osvojeni određeni sklopovi, uređaji i sistemi, bilo da su iz domaće proizvodnje ili iz uvoza, koji se ugrađuju u druga sredstva i koji imaju status nove proizvodnje. Za potrebe modernizacije nekog sredstva, u principu, razvijaju se i u proizvodnji osvajaju samo elementi potrebni za adaptaciju određenih sklopova i uređaja, vezni i stezni elementi.

\section{Postupak modernizacije}

Modernizaciju i modifikaciju određenog sredstva NVO mogu da predlažu svi učesnici u upotrebi i proizvodnji (taktički nosilac, nosilac razvoja, proizvođač, rukovalac, poznavalac sredstva, ...), ali procedura usvajanja svake modernizacije $i$ modifikacije je ista $i$ vrlo je slična proceduri za usvajanje u proizvodnju, odnosno naoružanje vojske određenog novog sredstva. Procedura osvajanja modernizacije i modifikacije određenog sredstva propisana je određenim normativnim aktima.

$\mathrm{U}$ proceduri donošenja odluke o modernizaciji određenog sredstva NVO moraju učestvovati nosioci planiranja i razvoja, proizvođači, taktički i tehnički nosilac i drugi po potrebi. Odluka o pristupanju modernizaciji je, svakako, u rukama taktickog nosioca.

Izvedena modernizacija određenog sredstva NVO prolazi proceduru usvajanja i verifikacije, kao i novoproizvedeno sredstvo NVO. Nije redak slučaj da se poboljsanjem karakteristika jednog sklopa - uređaja direktno ili indirektno ugrožava pouzdano funkcionisanje drugog sklopa ili uređaja. Da bi se to predupredilo mora se pre početka rada na konkretnoj modernizaciji dobro analizi- 
rati uticaj predviđenih poboljšanja na funkcionisanje sklopova i uređaja koji se ne modernizuju. U slučaju da se zaključi da ce predviđena poboljšanja negativno uticati na funkcionisanje bilo kog sklopa ili uređaja, taj negativni uticaj se mora sprečiti pravovremenom intervencijom na tom sklopu - uređaju.

Svi razvijeni sklopovi, uređaji i agregati koji se ugrađuju u modernizovano sredstvo mogu biti primenjeni kao originalni ili u modifikovanoj verziji (adaptirani - prilagođeni radi ugradnje u sredstvo).

Modernizaciji sredstava NVO u svetu posvećuje se velika pažnja, jer se na taj način, za razliku od nabavke novih sredstava, štede značajna novčana sredstva. Modernizaciju postojećih sredstava NVO treba ravnopravno razmatrati sa razvojem novih sredstava, zbog efekata koji se njome postižu.

\section{Osnovna pravila pri modernizaciji sredstava $N V O$}

Da bi se bilo koja modernizacija izvela neophodno je poštovati određena pravila koja se nameću kao obaveza pri radu na projektima modernizacije, a koja se ogledaju u sledećem:

- poboljšanje što više TTK konkretnog sredstva NVO, u što je moguće kraćem vremenu uz što manju cenu;

- razvoj sistema koji se mogu realizovati u vrlo kratkom vremenu;

- predlagač i izvođač modernizacije moraju razviti $\mathrm{i}$ ispitati kompletnu „lepezu“ poboljšanja TTK na konkretnom sredstvu, a potencijalni kupac, odnosno taktički nosilac, odabira ona rešenja ili varijante koje mu najviše odgovaraju. Projektant modernizacije mora da defi- niše minimum zahvata koji se moraju prihvatiti;

- sva pravila integralnog tehničkog obezbeđenja (ITOb-a) moraju se ispoštovati i njima posvetiti odgovarajuća pažnja;

- pre serijske proizvodnje, kompletno rešenje modernizacije i rešenja po segmentima (u svim varijantama), moraju biti detaljno ispitana po programu verifikovanom od odgovarajucég nivoa. Po završenom ispitivanju - verifikaciji, izrađenom i usaglašenom izveštaju, kao i pri osvajanju proizvodnje novih sredstava, od odgovarajucih nivoa odlucivanja, to rešenje mora biti prihvaćeno. Konkretno rešenje za konkretnog naručioca može biti ispitano $i$ verifikovano $i$ po posebnom programu usaglašenim sa kupcem - naručiocem;

- zahvate na osnovnom sredstvu, radi njegovog prilagođavanja za prihvat sklopova i uređaja za predviđenu modernizaciju, treba svesti na najmanju meru. Takođe, treba težiti da se spoljašnji izgled sredstva znatnije ne narušava.

\section{Primeri modernizacije borbenih vozila}

$\mathrm{Na}$ osnovu iznete logike i prateci svetska iskustva u modernizaciji sredstava, u našoj zemlji je u proteklom periodu razvijena $i$ realizovana $u$ odgovarajucoj seriji kompleksna modernizacija sledećih zastarelih sredstava NVO:

- samohodnog oruđa $90 \mathrm{~mm} \mathrm{M} 36$ B1;

- oklopnog automobila $30 / 2 \mathrm{~mm}$, Praga V3S;

- tenk $100 \mathrm{~mm}, \mathrm{~T}-55$.

Razvijene su, ispitane i usvojene, ali ne i realizovane kompleksne modernizacije sledećih sredstava NVO; 
- oklopno-izviđačkog automobila BRDM-2,

- samohodnog oruđa $76 \mathrm{~mm} \mathrm{M} 18$.

Zbog rata na prostoru naše zemlje, nije završen započeti razvoj modifikacija i adaptacija sledećih sredstava:

- automobila ZIL 131 i 157, zamenom benzinskog pogonskog motora savremenim dizel motorom veće snage $\mathrm{i}$ izmenama na transmisiji koje prate zamenu pogonskog motora;

- oklopnog transportera M 60 P i PB u sredstvo za mehanizovano polaganje mina (minopolagač) i u pokretnu tehničku radionicu;

- borbenog vozila pešadije M $80 \mathrm{~A}$, povećanjem vatrene moći ugradnjom kupole sa topom $30 \mathrm{~mm}$ i adaptacijom u pokretnu tehničku radionicu;

- terenskog automobila Pinzgauer $710 \mathrm{M}$ i ostalih modela, ugradnjom pouzdanog motora domaće proizvodnje;
- lovca tenkova na šasiji postojećeg oklopnog vozila, itd.

\section{Modernizacija tenka T-55}

Kompleksna modernizacija urađena je na srednjem tenku T-55. Značajnim poboljšanjima njegove bitne karakteristike dovedene su na nivo tenkova sledeće generacije. Područja mogućih modernizacija ovog tenka prikazana su na slici 1.

Na tenku T-55 ugrađen je top kalibra $100 \mathrm{~mm}$, pogonski motor snage $409 \mathrm{~kW}$, transmisija koja ima odvojene sklopove (multiplikator, menjač, bočni prenosi) sa svim pozitivnim i negativnim osobinama koje takav koncept organizacije transmisije daje. Tenk poseduje specifičnu snagu od $11,5 \mathrm{~kW} / \mathrm{t}$, razvija maksimalnu brzinu od $50 \mathrm{~km} / \mathrm{h}$, poseduje hodni uređaj koji omogućava pouzdano funkcionisanje u

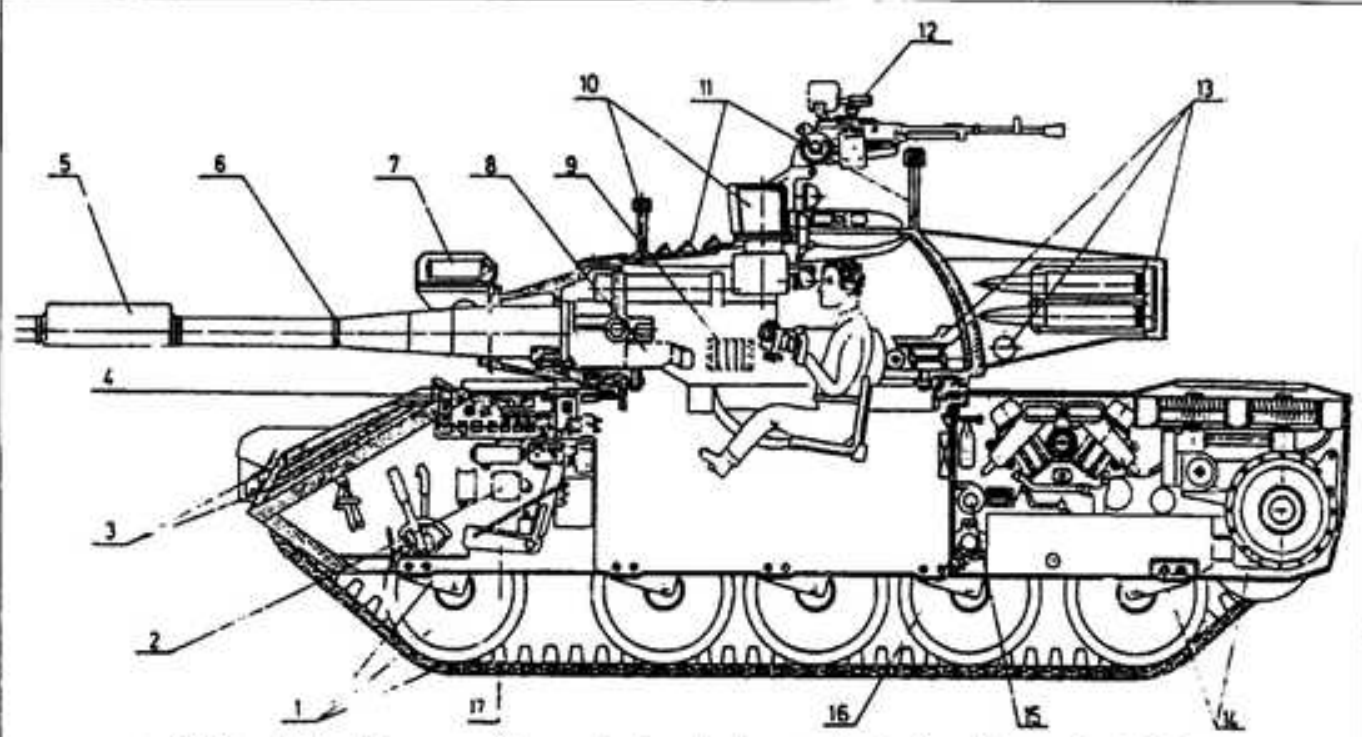

SI. 1 - Područja mogucih modernizacija konstrukcionih celina tenka T-55:

1 - elementi hodnog dela, 2 - sistem za pokretanje i zaustavljanje (start-stop), 3 - oklopna zastita, 4 - periskop, 5 - top $105 \mathrm{~mm}(125 \mathrm{~mm}), 6$ - obloga za termozastitu cevi topa, 7 - termovizijska kamera, 8 - filtroventilacioni uređaj. 9 - radio-uređaj RU 130 (ili slicni), 10 - meteo-senzor, 11 - laserski detektor, 12 -mitraljez 12,7 mm, 13 - automatski punjač topa, 14 -modularna pogonska grupa, 15 -klima-uređaj, 16 - generator elektricne energije, 17 - sediste vozača 
različitim uslovima kretanja i nema sistem za upravljanje vatrom. Ugrađeni top 100 $\mathrm{mm}$, u odnosu na topove koji se ugrađuju kod tenkova III i IV generacije (kalibra 105 do $125 \mathrm{~mm}$ ) je inferioran, i nema termičku zaštitu cevi.

Tenkovi sledeće, III generacije poseduju topove 105 do $120 \mathrm{~mm}$, specifičnu snagu preko $15 \mathrm{~kW} / \mathrm{t}$, maksimalnu brzinu preko $60 \mathrm{~km} / \mathrm{h}$, imaju sistem za upravljanje vatrom, itd. Tenk T-55 ima dobru oklopnu zaštitu, prihvatljivu siluetu, relativno dobar top i neke druge dobre karakteristike. Modernizacijom ce se dobre karakteristike očuvati a određene poboljsati radi dovođenja na nivo tenkova sledeće generacije.

\section{Postupak pri analizi konstrukcionih} rešenja radi njihovog poboljšanja

Postojeći top na tenku treba zameniti topom 105 ili $125 \mathrm{~mm}$ (to su aktuelni topovi u svetu na toj vrsti sredstava), radi povećanja vatrene moći i unifikacije municije. Poželjno je i racionalno na ovaj tenk ugraditi top $105 \mathrm{~mm}$, a za još veće povećanje vatrene moći pogodan je top $125 \mathrm{~mm}$. Preliminarna analiza je pokazala da se $i$ jedan $i$ drugi top mogu ugraditi u postojeću kupolu, ali da je za ugradnju topa $125 \mathrm{~mm}$ potrebno izvršiti velike i skupe adaptacije na kupoli kao i određena istraživanja, što je ocenjeno neracionalnim.

Moguća je brza i efikasna ugradnja topa $105 \mathrm{~mm}$, pošto se pri opaljenju granate bitno ne menjaju sile koje deluju na kupolu i tenk u celini. Za ugradnju ovog topa neophodne su manje adaptacije na zadnjaku i na vezi cevi i zadnjaka. $\mathrm{Za}$ rešenje ovog problema korišćena su iskustva dosadašnjih modernizacija.
Pored topa $105 \mathrm{~mm}$ moguća je ugradnja i sistema za upravljanje vatrom tipa SUV-T55 („Rudi Cajavec“, Banja Luka), ili sistema za upravljanje vatrom EFCS-3 („Iskra“, Kranj). Oba sistema su na ispitivanju pokazala dobre rezultate i usvojena su kao moguće rešenje modernizacije.

Kada je u pitanju zamena pogonske grupe polazi se od čnjenice da treba izvršiti analizu dinamičkih karakteristika postojećeg, kao i novog rešenja pogonske grupe. S obzirom na to da je planirana zamena kompletne pogonske grupe (motora, menjača, bočnih prenosnika sa pomoćnim uređajima i sistemima za upravljanje i promenu stepena prenosa) neophodna je provera mogućnosti da li hodni deo sa guseničnim pokretačem može da izdrži maksimalne brzine kretanja sa novom pogonskom grupom. Preliminarnom analizom mogućih karakteristika modernizovanog sredstva zaključeno je da se sa novom pogonskom grupom očekuju maksimalne brzine od oko $65 \mathrm{~km} / \mathrm{h}$, što predstavlja poboljšanje od oko $30 \%$.

Provera da li će hodni deo moći pouzdano da funkcioniše u uslovima maksimalne brzine kretanja sprovedena je kroz kontrolu uležištenja laktastih osovina, pogonskih, potpornih točkova i vodećih točkova kao i mogućnosti pouzdanog premotavanja gusenica preko pogonskih $\mathrm{i}$ vodećih točkova. Pored toga, proverena je mogućnost prihvatanja očekivanih oscilacija hodnog dela, sa postojećim elementima za njihovo prigušenje, pri kretanju po različitim vrstama terena. Detaljnom analizom konstrukcije može se zaključiti koje provere još treba izvršiti. Ukoliko se konstatuje da pojedini elementi ne zadovoljavaju, pristupa se rekonstrukciji vodeći računa da ona ne izazove neki novi poremećaj. Ukoliko se 
zaključi da će se to desiti, moraju se preduzeti preventivne konstrukcione mere.

Pored navedenih provera isto treba učiniti i na uležištenju i vezi kupole sa oklopnim telom, pošto ta veza mora pouzdano da funkcioniše bez obzira na intenzitet inercionih sila koje ce se pojavljivati ugradnjom nove pogonske grupe, zbog pojave većih ubrzanja i veće maksimalne brzine.

\section{Definisanje sistemskog rešenja za razvoj pogonske grupe}

Proverom gabaritnih dimenzija prostora u motorno-transmisionom odeljenju tenka, kao i dimenzija sklopova planiranih za ugradnju u pogonsku grupu zaključeno je da se može pristupiti modeliranju koncepcije pogonske grupe.

Analizirajući normativ vremena potrebnog za pojedine operacije pri određenim zahvatima korektivnog održavanja na motoru, menjaču i ostalim sklopovima transmisije, zaključeno je da su ta vremena velika, i da koncepcija transmisije sa posebnim sklopovima nije podesna za savremeno ratovanje, jer je vreme potrebno za dovođenje $u$ ispravno stanje $u$ proseku prilično dugo. Na primer, za zamenu pumpe za vodu motora V-55 tenka T-55 potrebno je preko $30 \mathrm{NC}$, a na zameni mogu da rade samo dva radnika, dok je za zamenu motora potrebno preko $50 \mathrm{NC}$, itd. I ovi podaci upućuju na to da se mora razmišljati o novoj koncepciji transmisije.

Analizom postojećih koncepcijskih rešenja transmisije, pa i kompletne pogonske grupe kod savremenih tenkova u svetu, došlo se do zaključka da treba razmotriti mogućnost postavljanja kompletne pogonske grupe na jednu plat- formu - postolje. Na taj način stvara se mogućnost brze zamene kompletne pogonske grupe, odnosno omogućava lakši pristup sklopovima radi intervencije, kada je pogonska grupa van tela tenka. To znači da pogonsku grupu treba formirati kao jedan modul, odnosno kao modularnu pogonsku grupu (MPG).

Imajući u vidu da je za modernizaciju pogonske grupe na tenku T-55 predviđeno da se koriste osnovni agregati i sklopovi razvijeni $\mathrm{i}$ ispitani na tenku $\mathrm{M}$ 84 , a u skladu sa definisanim i usvojenim principima i ekonomskim razlozima, na startu projektovanja predviđeno je razvijanje samo pomoćnih elemenata za vezu.

Pri modeliranju elemenata transmisije sa stanovišta dimenzija nove pogonske grupe, pojavio se problem rekonstrukcije ugradnje kompresora za vazduh. Zbog gabarita nije se moglo zadržati rešenje sa pogonom kompresora sa radilice motora, već se moralo naći novo rešenje, s tim da elementi pogona kompresora imaju iste parametre, kao i da ne bude poremećeno njegovo podmazivanje i hlađenje. U saradnji sa konstruktorom i proizvođačem kompresora, sa nebitnim odstupanjima parametara pogona (broj obrtaja), rešeno je da se kompresor ugradi na srednjem vratilu multiplikatora, uz mogućnost poboljšanja hlađenja (dovoda vazduha) na tom mestu.

Sledeće što je trebalo rešiti jeste smeštaj uređaja za hlađenje. Analizom gabarita pogona konstatovano je da se izmenjivaci toplote (hladnjaci) za tečnosti za hlađenje i podmazivanje kompletne pogonske grupe, kao i ventilator i pogon ventilatora, ne mogu smestiti na isti način kako je to rešeno kod tenka M 84 . Naime, to bi znatno promenilo siluetu tenka i zahtevalo rekonstrukciju njegovog zadnjeg dela (znatno produženje mo- 
torno-transmisionog odeljenja), cime bi se poremetilo definisano težiste tenka, $i$ imalo reperkusije na hodni deo modernizovanog tenka.

Od mogucih rešenja za ugradnju sistema za hlađenje konstatovano je da je jedino mesto gde je moguće da se postave hladnjaci za ulje i tečnost za hlađenje prostor iznad motora i transmisije (ispod poklopca motorno-transmisionog odeljenja). To automatski definiše i moguće rešenje za ugradnju ventilatora koji mora biti, takođe, u tom delu. Slično rešenje sistema za hlađenje sreće se na dosta tenkova zapadnog porekla, tako da se delovi, sklopovi i uređaji pogona ventilatora sa tih tenkova mogu koristiti, uz male dorade, i za pogon ventilatora kod ovog sredstva. Uz prethodni proračun sistema za hlađenje definisane su rashladne površine za pojedine fluide, kao i količina tečnosti za hlađenje. Takođe, proračunata je količina vazduha neophodna za odvod toplote, kako bi se na osnovu toga proračunali ventilatori (oblik lopatice, dimenzije kola, kao i brzine okretanja) i definisao tok strujanja vazduha. Ovaj deo rekonstrukcije zahteva detaljna ispitivanja i izradu varijantnih rešenja. Pri rešavanju problema hlađenja vodilo se računa o tome da motor i svi njegovi delovi treba da se definišu za rad na nominalnim režimima rada prema broju obrtaja i opterećenju. Ukoliko su tokom eksploatacije ovi uslovi bliži nominalnim, utoliko će pouzdanost i vek motora biti veći. Kod ekonomičnog i dobro projektovanog motora, sistem za hlađenje na nominalnom režimu opterećenja odvodi sledeću količinu toplote:

$\mathrm{Q}_{w}=(20-30) \% \mathrm{Q}_{\mathrm{g}}$,

gde je $\mathrm{Q}_{\mathrm{g}}$ količina toplote uneta $\mathrm{u}$ motor gorivom.
$\mathrm{Q}_{\mathrm{g}}=\mathrm{P}_{\mathrm{e}} \cdot \mathrm{g}_{\mathrm{e}} \cdot \mathrm{H}_{\mathrm{d}}$

gde je:

$\mathrm{P}_{\mathrm{e}}$ - snaga motora $(\mathrm{kW})$, kWh),

$\mathrm{g}_{e}$ - specifična potrošnja goriva $(g /$ $\mathrm{kg}$ ).

$\mathbf{H}_{\mathrm{d}}$ - donja toplotna moć goriva ( $\mathrm{kJ} /$

Ukupna količina toplote koju preuzima sistem hlađenja $Q_{w}$ zavisi od smeštaja motora, kao i načina hlađenja ulja i drugih fluida u motoru.

Sa porastom potrošnje goriva raste $\mathrm{i}$ termičko opterećenje svih delova - unutrašnje, i svih sistema - spoljašnje. Zbog toga je stanje sistema za hlađenje vrlo važan indikator stanja kompletne pogonske grupe, jer se svi problemi u radu manifestuju preko tog sistema.

$\mathrm{Na}$ nižim i višim brojevima obrtaja motora specifična potrošnja goriva raste, pa je $Q_{w}$ složena funkcija, ali u principu ima oblik prikazan na slici 2 za letnje i zimske uslove rada. Leti su uslovi za izmenu toplote nepovoljniji, jer je temperatura okoline viša, pa je manja razlika u temperaturi rashladnih fluida i okoline. Radi toga sistem za hlađenje se mora

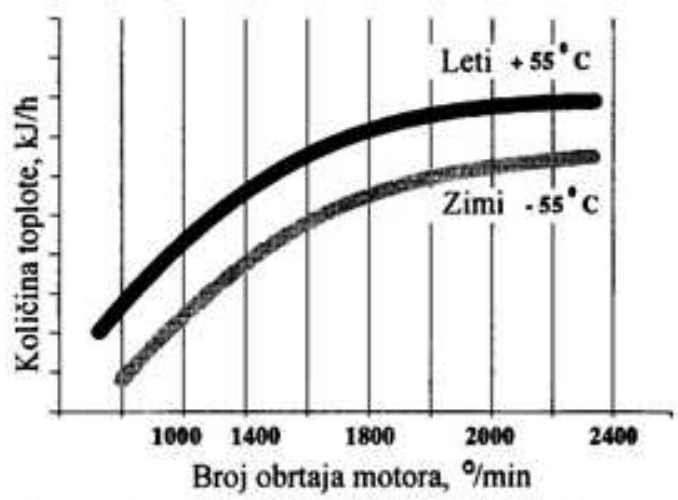

Sl. 2 - Količina toplote koju odvodi sistem za hladenje $\mathrm{Q}_{\mathrm{w}}$

(srednje vrednosti $z a \mathrm{n}_{\max }$ ) 


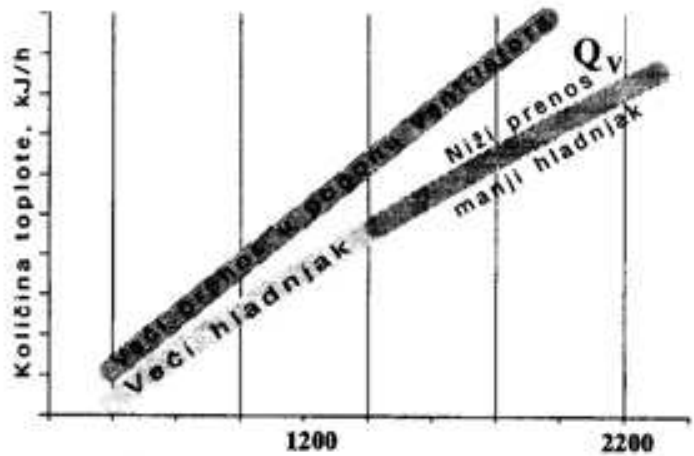

Sl. 3 - Količina toplote koju może odvesti sistem za hladenje

(ventilator sa reduktorom i dve vrste hladnjaka)

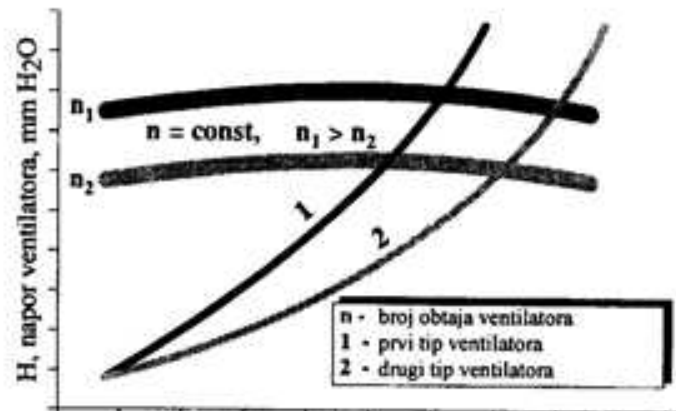

Protok vazduha, $\mathrm{G}_{\mathrm{v}}, \mathrm{kg} / \mathrm{s}$

SI. 4 - Karakteristika ventilatora $u$ sistemu za hladenje

(zavisnost napora $\mathrm{H}$ od protoka vazduha $\mathrm{G}_{\mathrm{v}}$ za razlicite konstrukcije)

projektovati prema zahtevima visokih temperatura okoline.

Sistem za hlađenje preuzima količinu toplote srazmerno protoku vazduha, tako da je on ključni parametar za termoregulaciju. Količina vazduha koju može odvesti sistem za hlađenje $G_{v}$ zavisi od otpora u sistemu i napora ventilatora (slika 3 ).

Protok vazduha može se regulisati:

- promenom otpora u sistemu (promenom dimenzija hladnjaka i ugradnjom automatskih žaluzina);

- promenom broja obrtaja i tipa ventilatora (slike 3 i 4);
- odvajanjem pogona ventilatora od radilice motora.

Najčešći problemi kod izvedenih sistema za hlađenje su:

- nije uspostavljena prirodna ravnoteža, odnosno u svim uslovima eksploatacije nije obezbeđen uslov $\mathrm{Q}_{v}=\mathrm{Q}_{w}$;

- na nižim brojevima obrtaja $\mathrm{Q}_{\mathrm{w}}>\mathrm{Q}_{\mathrm{v}}$ motor se pregreva pri punom gasu;

- na višim brojevima obrtaja $\mathrm{Q}_{\mathrm{v}}>\mathrm{Q}_{\mathrm{w}}$ motor je pothlađen, što ima za posledicu veći gubitak snage zbog pogona ventilatora, veću potrošnju goriva i kraći vek motora.

Da bi se navedeni problemi rešili ugrađuju se ventilatori sa više stepeni prenosa (najčešce dva), kao i termostat u sistemu hlađenja. Prednosti sistema za hladenje sa ovakvom regulacijom su u tome sto:

- motor uvek radi u termički optimalnom režimu, pa se oslobađa snaga za pogon ventilatora;

- niža je potrošnja goriva;

- motor postaje neosetljiv na promene uslova okoline.

Poštujući ove osnovne postavke moguće je optimalno projektovanje sistema za hlađenje i kod sredstava koja se modernizuju.

Rešavanje konstrukcionih problema pri modernizaciji tenka $T$-55

Prilikom modernizacije tenka T-55 rešen je niz problema, kao što su:

- funkcionisanje sistema komandi za promenu stepena prenosa, upravljanje $\mathrm{i}$ zaustavljanje.

Rekonstrukcija je izvedena tako što je uvedena poluautomatska $\mathrm{i}$ automatska promena stepena prenosa, što nije bilo zastupljeno rešenje u naoružanju VJ. Sve 
komande izvedene su pomoću brzorastavljivih veza. Poluautomatska i automatska promena stepena prenosa izvedena je tako da se na osnovu parametara o brzini kretanja tenka, broju obrtaja motora i uključenom stepenu prenosa automatski menja stepen prenosa i usklađuje sa situacijom (potrebama), odnosno mogućnostima tenka i vozača;

- brzo spajanje i rastavljanje creva za dovod tečnosti za hlađenje i podmazivanje, sabijenog vazduha i kablova za električno napajanje.

Globalno je rešeno da se izlazi iz pogonske grupe svih fluida, sabijenog vazduha i priključaka za električno napajanje realizuju na pogodnom (pristupačnom) mestu, na tabli pričvršćenoj na pogonskoj grupi. Brzo rastavljanje i sastavljanje creva za razne fluide rešeno je preuzimanjem konstrukcionih rešenja primenjenih na avionima, odnosno korišcenjem brzorastavljivih spojnica. Isto rešnje primenjeno je i kod raznih konektora u sistemu za spajanje elektroinstalacije;

- spajanje pogonske grupe sa telom tenka i sa pogonskim točkovima.

Kompletna pogonska grupa izvedena je na ramu - Sasiji. Njena veza sa oklopnim telom rešena je pomoću dve ploče kojima se, na prednjem delu, oslanja i povezuje za pod oklopnog tela. Sa zadnje strane povezana je za pogon hodnog dela preko izvoda za pogonski točak. S obzirom na to da je ova konstrukcija kod tenka M 84 , sa bočnim reduktorom i vratilom pogonskog točka sa bočnim menjačem, izvedena u jednom kućištu, ta veza se morala rastaviti. Prihvaćeno je rešenje da se odvoje bočni menjači od bočnih reduktora, a da se bočni reduktori postave kao kod tenka T-55, s tim da se posebno realizuje brzorastavljiva évrsta veza menjača i bočnog reduktora, sa zatvaranjem bočnog menjača.

- usmeravanje protoka vazduha kroz pogonsku grupu.

Usmeravanje protoka vazduha urađeno je prema sličnim rešenjima primenjenim na drugim tenkovima. Pri ispitivanju u terenskim uslovima (laboratorijskih nije bilo), konstatovano je da dolazi do mešanja struja vazduha, tj da se topli vazduh ponovo usisava. Problem je rešen postavljanjem usmerivača vazduha.

Kompletno rešenje ugradnje i veze pogonske grupe urađeno je tako da se omoguci njena brza zamena (sa prosečno obučenom posadom u terenskim uslovima za manje od $\mathbf{4 0}$ minuta).

$\mathrm{Na}$ osnovu uradene analize, proracuna i konstrukcije proizveden je prototip modularne pogonske grupe koja je prikazana na slici 5 .

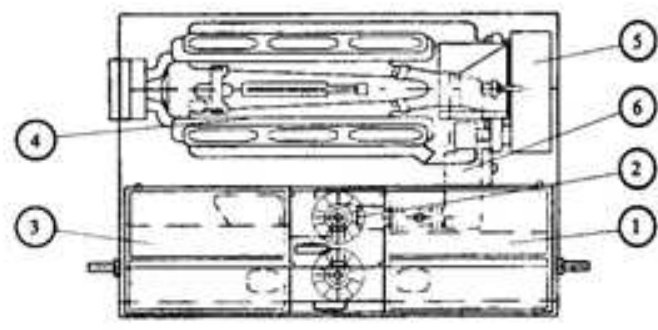

Sl. 5 - Modularna pogonska grupa: 1 i 3 - bočni menjači, 2 - ventilator, 4 - pogonski motor, 5 - precistač vazduha, 6 - multiplikator

Ovako koncipirana i proizvedena modularna pogonska grupa je ispitana, izvršena homologacija, a nakon toga započeta serijska proizvodnja.

\section{Zaključak}

Modernizacijom sredstava NVO moguće je ostvariti izuzetno racionalno i ekonomično opremanje vojske efikasnim 
i ubojitim sredstvima. Da bi se modernizacija racionalno realizovala neophodni su permanentni napori na razvoju novih sredstava, čije se komponente mogu koristiti za modernizaciju sredstava NVO koja su više godina u upotrebi. Na taj način postižu se dvostruki pozitivni efekti.
Lìteratura:

[1] Lazarevic, D.: Režimi opterećenja transmisija brzohodnih gusenicnih vozila, doktorska disertacija, VTA, Beograd. 1996.

[2] Janicijevic, N.: Automatsko upravljanje na motornim vozilima, MF, Beograd, 1993.

[3] Veinovic, S.: Materijal pripremljen za rad ekspertske grupe. Krußevac, 1994. 